\title{
Performance Evaluation of Biomass Briquette from Elephant and Spear grass in Benin City, Edo State, Nigeria
}

\author{
P.O. Ebunilo, E.K. Orhorhoro, C. M.Chukwudi and I.A Essienubong
}

\begin{abstract}
This research work is aimed at the performance evaluation of biomass briquette from elephant and spear grass in Benin City, Edo State, Nigeria. The grasses were dried, pulverized and compressed by the briquetting machine to produce the briquettes. The performance evaluation shown that elephant and spear grass briquettes had a good compressive strength between $2.0 \mathrm{~N} / \mathrm{mm}^{2}$ and $1.2 \mathrm{~N} / \mathrm{mm}^{2}$; ash content $(5.18 \%$ and $6.13 \%)$ and calorific values $(15013.9 \mathrm{KJ} / \mathrm{Kg}$ and $15990.0 \mathrm{KJ} / \mathrm{Kg}$ ) respectively. The briquettes produced when burnt have low ash content. Therefore, if biomass briquetting is fully harnessed, it will curb the energy crises in Nigeria and the same time creates employment opportunities from briquette sales.
\end{abstract}

Index Terms - Biomass briquette, Elephant grass, Spear grass, Benin City, Edo State, Nigeria.

\section{INTRODUCTION}

Availability of cheap energy (affordable and unfailing energy supply) and its efficient utilization is essential, if not the most critical factor in developmental activities of any nation. It is one of the indispensable factors for continuous development and economic growth [1]. However, there is a problem of energy in developing countries and this is mainly due to urbanization, industrialization, technological advancement etc., which have brought energy demand in a place like Nigeria under an increased pressure. As a result, a greater percentage of the ever-growing population of Nigeria now depends on the country's forest wood as a source of fuel wood for domestic and small-scale industrial activities in urban, semi urban and rural areas. Nigeria's forests, which currently extend over 9.6 million hectares, have been dwindling rapidly over the past decades [2]. In the year 2013, the rate of deforestation in Nigeria was estimated at $3.7 \%$, which is one of the highest in the world as reported by the United Nation Collaborating Programme on Reducing Emissions from Deforestation and Forest Degradation in Developing Country [3].

Manuscript published July 31, 2016

P.O. Ebunilo is with Department of Mechanical Engineering, Faculty of Engineering, University of Benin. Benin City, Edo State, Nigeria. (e-mail: Patrick.ebunilo@uniben.edu)

E.K. Orhorhoro is with Cemek Machinery Company, Technology Incubation Centre, Federal Ministry of Science \& Technology. Benin City, Edo State, Nigeria (e-mail: kelecom@yahoo.com)

C. M.Chukwudi is with Department of Mechanical Engineering, Faculty of Engineering, University of Benin. Benin City, Edo State, Nigeria (email: michealgreat4promise@yahoo.com)

I.A Essienubong is with Department of Mechanical Engineering, Faculty of Engineering, Universty of Benin. Benin City, Edo State, Nigeria (e-mail: ikpeaniekan@gmail.com)
To address the energy challenge in Nigeria, scientists and engineers are exploring other biomass resources namely: energy crops (grasses), agricultural waste, municipal waste, and shrubs as viable feedstock for energy production. The use of perennial grasses (also known as energy crops) which neither compete with human food supply nor contribute to deforestation is currently been exploited by scientists and engineers alike [4]. As biomass, it serves as carbon sink by sequestering carbon in soil and has very low sulfur and ash content [5].

Elephant grass also known as Napier grass, Uganda grass or giant king grass is a tall grass that originated from subSaharan tropical Africa [6]. Elephant grass is an indigenous grass found all over the tropics, in Nigeria, it is one of the dominating grasses found in farmlands and non-agricultural fields. Spear grass (Imperatacylindrica) is a rhizomatous, perennial grass weed and quite a fast-growing grass which is widely distributed throughout the humid, sub-humid tropics and some parts of the warm temperate regions of the world It grows on wet lands, dry lands, areas of high salinity, organic soils; clay soils, sandy soils of $\mathrm{pH}$ from 4.0 to 7.5 and in open areas. The plant has become naturalized in Africa, Americans, Northern Asia and Europe. Worldwide it has been observed from $45^{\circ} \mathrm{N}$ to $45^{\circ} \mathrm{S}$ and is ranked as the world's seventh worst weed [7]. In Benin City, Edo State, Nigeria, it is one of the most dominant and noxious weeds in agricultural and non-agricultural areas.

Researchers have shown that a cleaner, affordable fuel source which is a substitute to fuel wood can be produced by blending and compressing these perennial grasses, coals, sawdust etc. into biomass briquettes ([8]; [9]; [10]). Biomass briquetting process is defined as the process of converting low bulk density biomass into high density and energy concentrated fuel briquettes. It is an alternative fuel used for thermal applications in various industries like ceramics, food processing, steel industries, power generation etc. Adoption of briquette technology will not only create a safe and hygienic way of disposing the biomass waste, but turn into a cash rich venture by converting waste into energy and also contributing towards a better environment. This research work is aim at performance evaluation of biomass briquette from elephant and spear grass in Benin City, Edo State, Nigeria. 


\section{EXPERIMENTAL PROCEDURE}

\section{A. Materials}

The materials used include the following: Fully grown spear grass (Imperatacylindrica) and elephant grass (Pennisetumpurpureum) were collected from an open grass land in Benin City, Edo State, Nigeria, hydraulic briquette machine, bomb and canister, oxygen bomb calorimeter, weighing balance, electric oven, electric furnace, crucibles, Philips digital balance model NT 103, desiccator, nickel fuse wire, sieve and clean water.

\section{B. Experimental Test}

The collected spear grass (Imperatacylindrica) and elephant grass (Pennisetumpurpureum) were air-dried for ten days to reduce moisture content of the materials. The collected grass samples were chopped to about $10 \mathrm{~cm}$ length, grounded using a diesel operated grinding machine to fine particle sizes and sieved. This was now compressed by hydraulic briquette machine locally made in Benin City, Edo State, Nigeria.

The calorific value of materials was determined using XRY-1A digital oxygen bomb calorimeter. The calorific value was calculated as shown.

$$
\mathrm{Q}=\frac{C \Delta T-(\mathrm{e} 1+\mathrm{e} 2+\mathrm{e} 3)}{\mathrm{m}} \mathrm{KJ} / \mathrm{Kg}
$$

The ash content of the samples was calculated as follow.

$$
\text { Ash content }(\%)=\frac{\text { Mass of ash }}{\text { Mass of sample }} \times \frac{100}{1}
$$

\begin{tabular}{|c|c|c|c|}
\hline Samples & $\begin{array}{l}\text { Weight of } \\
\text { raw sample } \\
(\mathrm{g})\end{array}$ & $\begin{array}{l}\text { Moisture } \\
\text { content }\end{array}$ & $\begin{array}{l}\text { Calorific value } \\
(\mathrm{KJ} / \mathrm{kg})\end{array}$ \\
\hline Elephant grass & 20 & 14.26 & 14231.3 \\
\hline Spear grass & 20 & 13.14 & 14011.2 \\
\hline \multicolumn{4}{|c|}{ TABLE II-a: BRIQUETTE ANALYSIS } \\
\hline Samples & $\begin{array}{l}\text { Weight } \\
\text { Fuel } \\
\text { sample }\end{array}$ & $\begin{array}{l}\text { Moisture } \\
\text { content }(\%)\end{array}$ & $\begin{array}{l}\text { Ash content } \\
(\%)\end{array}$ \\
\hline $\begin{array}{l}\text { Briquette of } \\
\text { Elephant grass }\end{array}$ & 20 & 10.26 & 5.18 \\
\hline $\begin{array}{l}\text { Briquette of Spear } \\
\text { grass }\end{array}$ & 20 & 10.14 & 6.13 \\
\hline $\begin{array}{l}\text { Briquette of } 50 \% \\
\text { elephant grass }+50 \% \\
\text { Spear grass }\end{array}$ & 20 & 10.10 & 5.78 \\
\hline Fuel wood & 20 & 12.44 & 7.54 \\
\hline Kerosene & 20 & - & - \\
\hline \multicolumn{4}{|c|}{ TABLE II-b: BRIQUETTE ANALYSIS } \\
\hline \multicolumn{2}{|l|}{ Samples } & $\begin{array}{l}\text { Calorific } \\
\text { Value } \\
(\mathrm{KJ} / \mathrm{Kg})\end{array}$ & $\begin{array}{c}\text { Compressive } \\
\text { Strength } \\
\left(\mathrm{N} / \mathrm{mm}^{2}\right)\end{array}$ \\
\hline \multicolumn{2}{|l|}{$\begin{array}{l}\text { Briquette of } \\
\text { Elephant grass }\end{array}$} & 15013.9 & 2.0 \\
\hline \multicolumn{2}{|l|}{ Briquette of Spear grass } & 15990.0 & 1.2 \\
\hline \multicolumn{2}{|c|}{$\begin{array}{l}\text { Briquette of } 50 \% \text { elephant grass + } \\
50 \% \text { Spear grass }\end{array}$} & 15333.0 & 1.6 \\
\hline \multicolumn{2}{|c|}{ Fuel wood } & 17400 & - \\
\hline \multicolumn{2}{|l|}{ Kerosene } & 35000 & - \\
\hline
\end{tabular}

TABLE I: PROXIMATE ANALYSIS OF THE RAW SAMPLES

\section{RERESULTS AND DISCUSSION}

The results obtained showed that the calorific values of spear grass and elephant grass briquettes were $15990.0 \mathrm{KJ} / \mathrm{kg}$ and $15013.9 \mathrm{KJ} / \mathrm{kg}$ respectively. Considering the calorific values of the plant materials before briquetting, it was shown that there is an increase in the calorific value after convection of the raw grass samples into briquettes. The spear grass and elephant grass had calorific values of $14011.2 \mathrm{KJ} / \mathrm{kg}$ and $14231.3 \mathrm{KJ} / \mathrm{kg}$ respectively before briquetting (Table 1). This increase is partly attributed to the slight difference in the moisture content of the materials; as at the time of the analyses, elephant grass and spear grass had moisture content of $14.26 \%$ and $13.14 \%$ respectively while their briquettes had moisture contents of $10.26 \%$ and $10.14 \%$ respectively. Comparing the heating values of the briquettes with those of firewood (Table II) shows that their calorific value is close and also their low ash content makes it a perfect alternative to fuel wood and kerosene. From the results of compressive strength, elephant grass and spear grass briquette has a compressive strength of 2.0 and 1.2 respectively.

\section{CONCLUSION}

The result of the research work shown that energy crops (elephant or spear grasses) briquettes can be used for both industrial and domestic purposes. A high quality briquette with a good compressive strength, good calorific value and less ash content were obtained. Other benefits which are listed below can be obtained from the research work:

1) Biomass briquetting, if fully harnessed will curb the energy crises in Nigeria and create employment opportunities from briquette sales.

2) This technology helps in the conversion of waste to wealth and also promotes our technology and local content. More so, it is environment friendly, reducing the health hazards caused by indiscriminate bush burning and greenhouse gas emissions.

\section{REFERENCES}

[1] J.F.K. Akinbami, Renewable Energy Resources and Technologies in Nigeria, Present Situation, Future Prospects and Policy Framework. Migration and Adaptation Strategies for Global Changes, vol 6, no.2, pp. 155 - 181, September 2001

[2] Energy Commission of Nigeria, Potential for renewable energy application in Nigeria, pp. 1-2, July 1997

[3] The United Nations Collaborative Programme on Reducing Emissions from Deforestation and Forest Degradation in Developing Countries (UN-REDD), (2013). REDD+ Strategy Programme.

[4] K. P.Woli, M.B David., J. Tsai J, T.B Voigt, R.G Darmody, and C.A. Mitchell "Evaluating silicon concentrations in biofuel feedstock crops Miscanthus and Switchgrass”. Bio and Bioenerg,35: 2807-2813, 2011

[5] V. Strezov, T.J Evans, and Hayman C, (2008). "Thermal conversion of elephant grass pennisetumpurpureun varieties to biogas, bio-oil and charcoal". Bioresources Technology, pp. 8394-8399, November 2008

[6] W.D Clayton, R. Govaerts, K.T Harman, H. Williamson, and M. Vorontsova, World checklist of Poaceae. Richmond, UK: Royal Botanic Gardens, Kew, 2013

[7] A. Aminah A., C.C Wong and P.K Eng, "Techniques for rapid vegetative multiplication for pasture species and commercial production", Regional Forage Development, FAO, Rome, pp 167-178, May 1997

[8] P.D. Grover, and S.K. Mishra, Biomass Briquetting: "Technology and Practices. Regional Wood Energy Development Program in Asia, field document 46". Food and Agricultural Organization of the United Nations, Bangkok, Thailand, 1996. 
[9] F. Olle, N. Olof, Biomass Briquettes in Malawi, Degree Project, Department of Management and Engineering, Institute of Technology, Linkoping University, Malawi, May 2006

[10] C.O. Adegoke, "Sawdust briquettes as a case Study", Paper Presented at the Mechanical Division of Nigerian Society of Engineers Conference Ibadan, May 2001

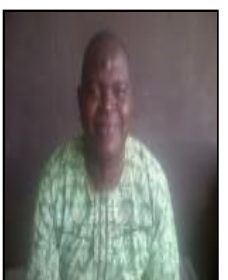

Patrick Okechukwu Ebunilo B. Eng (Asutech), M.Sc (University of Lagos, Lagos State, Nigeria) PhD. (University of Benin, Benin City, Edo State, Nigeria); MNSE, Reg. (COREN); Associate, Professor of Design and Manufacture, Department of Mechanical Engineering, University of Benin, Benin City, Edo State, Nigeria,

Patrick.ebunilo@uniben.edu.

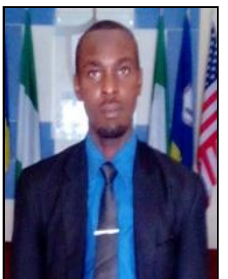

Ejiroghene Kelly Orhorhoro B. Eng \& M. Eng (2010 \& 2014 respectively): University of Benin, Benin City, Nigeria; PhD student, Department of Mechanical Engineering, University of Benin, Benin City, Edo State, Nigeria. Cemek Machinery Company, Technology Incubation Centre, Federal Ministry of Science \& Technology, Benin City, Edo State, Nigeria,

kelecom@yahoo.com

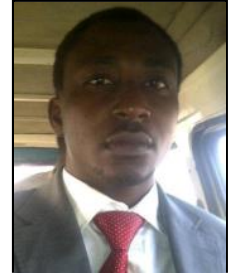

Micheal Chukwudi Okonkwo B. Eng \& M. Eng (2010 \& 2016 respectively): University of Benin, Benin City, Edo State, Nigeria.

michealgreat4promise@yahoo.com

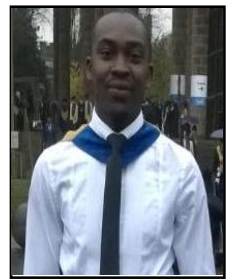

Essienubong Aniekan Ikpe B. Eng. Mechanical Engineering 2010- University of Uyo, Akwa Ibom State. Nigeria; M.Sc (2014)- Coventry University, United Kingdom. PhD student, Department of Mechanical Engineering, University of Benin, Benin City, Edo State, Nigeria

ikpeaniekan@gmail.com 